\title{
Meeting Standards through Integrated Curriculum: Point of View by Sussan M. Drake and Rebecca C. Bruns
}

\author{
Taseman1, Wilujeng Asih Purwani ${ }^{2}$, Safarudin ${ }^{3}$, Nasrul Fuad Erfansyah", \\ Ratna Pangastuti ${ }^{5}$, Abd. Malik Dachlan ${ }^{6}$, Nukh Khozain ${ }^{7}$ \\ 1Institute University of Islamic Al Khoziny, Sidoarjo, Indonesia \\ ${ }^{2}$ University of Billfath, Lamongan, Indonesia \\ 3 IAIM Sinjai, Indonesia \\ 4,5Islamic State University of Sunan Ampel, Surabaya, Indonesia \\ 6Tarbiyah High School of Al Ibrohim, Madura, Indonesia \\ 7Tarbiyah High School of Al Fattah, Lamongan, Indonesia
}

\begin{tabular}{|c|c|}
\hline Book Review Info & ABSTRACT \\
\hline Book Review history: & Through an integrated curriculum, it is expected that the fulfillment of a \\
\hline Received April 14, 2020 & maximum standard of learning for students' problems while learning, \\
\hline Accepted April 16, 2020 & the integrated curriculum will determine the content, processes, \\
\hline Published April 19, 2020 & $\begin{array}{l}\text { materials, and learning materials that teachers do to students in the } \\
\text { classroom. Students who have problems are expected to be able to }\end{array}$ \\
\hline Keywords: & overcome the problem both those who lack achievement and are left \\
\hline Meeting Standards & behind, the evaluation carried out is also expected to be able to measure \\
\hline Curriculum & the ability of students to improve learning that has been done, besides it \\
\hline Integrated Curriculum & can be compared between one school to another with an evaluation. So \\
\hline Point of View & $\begin{array}{l}\text { we need a standard-based approach and an integrated curriculum, the } \\
\text { second offers several strategies in developing an integrated curriculum } \\
\text { that has been proven in its implementation, thirdly to validate an } \\
\text { integrated curriculum by offering examples of integrated curricula that } \\
\text { have proven to be successful. }\end{array}$ \\
\hline
\end{tabular}

The integrated curriculum has its own history. The emergence of standards-based education is the origin of the integrated curriculum. Integrated curriculum development is very possible in today's education. Teachers must begin to become familiar with the standards-based curriculum where they can begin to integrate the field of curriculum. The teacher must realize that standard demands are not the only individual tasks that students must do. The teacher can discuss standards together in groups both inside and outside the discipline. After teachers understand how the standards are related, they must have perceptions about the integrated curriculum. The teacher can see it as the only way to teach and achieve standards.

An interdisciplinary approach to achieving standards requires more creative learning. The problem is creative and innovative learning does not always lead to increased student achievement. Curriculum standards can be used to solve this problem. Using curriculum standards as a guide, learning can achieve goals. Many teachers see the potential of an integrated curriculum. With an integrated curriculum, students will gain trust that encourages their interdisciplinary spirit, focus learning on knowledge and skills, process information using various technology strategies, analyze and explain the impact of interdisciplinary approaches on society and find solutions for real life situations. 
Some countries are interested in an integrated curriculum approach. The integration of science, mathematics and technology in Australia shows that this approach works well. Lang from Germany applies an integrated approach to science. The main feature of his work is to use a collaborative process to decide what needs to be known. In China, Japan, Korea, and Taiwan, teachers develop an integrated curriculum after they realize that the approach so far has been dominated by conventional approaches that do not support understanding, creativity, or social interests.

In Taiwan, curriculum for grades 1 through 9 replaces traditional learning with seven main domains of learning. The domains are language and literature, health and physical education, social sciences, arts and humanities, mathematics, nature and technology, and integrated activities. The teacher designs this curriculum to avoid students limiting material and develop students' ability to integrate learning. The curriculum is related to humanity and student character. Students learn basic skills by reading textbooks and integrating skills in real life. Teachers can develop curricula, but they must take responsibility for students to learn. The aim of the integrated curriculum is for students to understand change and real life so that they become responsible members of society. Japan has shortened the curriculum in primary and secondary schools. Teachers must devote additional learning time to teaching material that is not in textbooks and that is not in curriculum standards. The aim is to teach students how to learn, how to do research, and how to be more creative.

This book has three main objectives: (1) To explain teachers about the standards-based approach and integrated curriculum; (2) To offer several strategies in developing integrated curricula that have been proven in their implementation; (3) To validate integrated curriculum by offering examples of integrated curricula that have proven successful. For this reason, this book describes how to develop an integrated curriculum and examples of how to apply it. This book also explains the teacher's responsibilities when teaching with an integrated approach and must successfully overcome accountability issues such as maximizing student achievement and preparing standardized testing.

Innovative teachers will always try to improve student achievement in various ways and one of them is by making a curriculum that is rigorous, relevant, and interesting. When students take time after school by participating in a real-life environment, will their test scores in the subject increase? In Florida, Okhee Lee, an education professor at the University of Miami, engages elementary school students in making wind and rain. Students focus on several concepts such as evaporation, condensation, and heat energy. Although student learning outcomes are not measured by tests, students have shown more than an understanding of what is tested on the test. Lee claims that when he teaches scientific concepts, he also teaches students to think and write in a structured way (Barry, 2001). At public schools in Asheville and Buncombe, North Carolina, students learn math skills by dancing and exploring the solar system through modern dance. In this school, the teacher provides a core curriculum through art. This approach is based on research reports on the impact of art on learning. This report shows evidence that the involvement of art and theater correlates with success in learning mathematics and reading.

Based on the above example, student achievement is the main focus. The teacher maintains accountability by designing learning experiences that are relevant to students' interests. The teacher develops an interesting curriculum that crosses the boundaries of scientific disciplines to obtain positive learning outcomes. The above example explains the potential of an integrated curriculum in improving student achievement. 
What is an integrated curriculum? In a simple concept, integrated is making a connection. What type of connection? Does it cover all disciplines? Is it needed for real life? Is the connection skill-based or knowledge-based? The definition of integrated curriculum has been a subject of discussion since the beginning of the 20th century. Over the last hundred years, experts have offered three basic categories of integrated concepts. Integrated refers to the combination of two subjects under the control of the same teacher. Integration can also be explained as a union of all subjects and experiences. To define an integrated curriculum, there are three approaches namely multidisciplinary, interdisciplinary, and transdisciplinary integration. Multidisciplinary Integration. The multidisciplinary approach focuses mainly on several disciplines. Teachers who use this approach manage several disciplines on a particular theme. Interdisciplinary Integration. In this approach, the teacher sets the curriculum for all disciplines. They emphasize interdisciplinary skills and concepts. As an example of this approach, students learn about wind and rain while learning language skills. They learn communication skills (structured and coherent thinking and writing). The teacher focuses on the concepts of evaporation, condensation, and heat energy. These concepts are transferred from and to other lessons so learning can develop higher-order thinking. Other examples students learn mathematics, science and skills while singing, making sculptures and paintings and dancing. Artists can collaborate with teachers to develop integrated learning that remains focused on standards. Transdisciplinary Integration. In the transdisciplinary approach, the teacher arranges the curriculum for several things. Students develop life skills because they apply interdisciplinary skills and discipline in real life contexts. There are two pathways that lead to transdisciplinary integration; that is project based learning and curriculum negotiation.

Some teachers assume that they have no reason to integrate the curriculum. However, educational organizations often recommend curriculum integration. The National Mathematics Teachers Council, for example, suggests connecting mathematics with real life situations and other subjects. Recommendations for the integrated curriculum so far have not been widely implemented. This is due to certain scientific experts writing curricula for their disciplines. In addition, many teachers do not understand the integrated curriculum. There is no clear formulation of its implementation. Many teachers are not comfortable with the fields of science that he is not engaged in. But for most other teachers, the integrated curriculum is the most logical way in the 21st century.

Accountability in education can be seen as students learn what they are supposed to learn. In the school system, evaluation and assessment procedures are a type of accountability. Unfortunately, student assessment results often never reach the level expected by teachers and parents. This leads to the conclusion that the school and the school system are not optimally doing their jobs. In schools that have carried out external evaluations well, the key factor for student success is a coherent curriculum. A coherent curriculum means that teachers and students, learning objectives, activities, and assessments have positions that are parallel to one another.

The process of designing an integrated curriculum will maximize coherence both vertically and horizontally. This process will identify overlaps in lessons and strengthen the continuity of learning from class to class. Using this process, teachers find it easier to design integrated learning units because of the understanding of each discipline. In addition, the teacher will regularly review student performance results (both in class and during assessment) to identify certain skills and understanding important concepts. For most teachers, the strength of an interdisciplinary curriculum is that teachers can arrange 
it in contexts that are relevant to students and according to their needs. Two strategies for increasing relevance are (1) starting with questions from students and (2) organizing learning in a local context. Integrated curriculum is regulated in the local context be it cultural, political, economic, or natural social environment. The characteristics of education in the integrated curriculum are as follows: (1) Students as producers of knowledge rather than consumers, (2) Teachers as guides rather than instructors. (3) Student questions are central to the curriculum. (4) The teacher incorporates many subjects into the investigation. (5) Students solve real problems.

Integrated curriculum leads to a curriculum that is very strict, but easy to adapt to different contexts. Of course, the emphasis on local interests in project-based and localbased learning causes the curriculum to be different in each location. However, the scope and sequence provided by the standard remains intact. Content, assessment procedures, and learning strategies remain in line with standards. When teachers have the freedom to develop curriculum, they will be creative in adapting to diverse student needs. With individual needs, the teacher can help all students achieve higher learning outcomes.

Teachers often face diverse students. Among the questions teachers often face are: "How do we meet the needs of students who have different levels of ability?" and "How do we motivate all students to learn?" With these conditions, an integrated curriculum approach will effectively be able to serve all students. In addition, teachers can work together to direct students to learn, increase participation and complete assignments, increase understanding of concepts and skills, improve connections across disciplines, be more disciplined, and increase student attendance in learning. The teacher sees positive effects especially with students at risk. Teachers who apply an integrated approach are teachers who are able to engage each student. Teachers tend to consider multiple intelligences, learning styles, and apply various approaches that optimize learning for students.

The results show evidence that with an integrated curriculum students can learn through integrated approaches and can continue higher education successfully. Based on the results of these studies, universities proposed various stringent requirements for prospective students. As a result, schools will always try to carry out student-centered learning and teach skills that are oriented to what is needed to live a democratic life. Schools that implement integrated curriculum will have better graduates compared to schools that implement traditional curriculum. Student responses to the integrated curriculum are generally very positive. Most students are enthusiastic in learning because they learn three aspects; material content, social skills, and engaging activities. With an integrated curriculum, students learn from a fun curriculum and offer group work options. Students value real-world situations and work in depth on projects or questions. Students get the opportunity to learn various skills and social skills. With an integrated curriculum good learning is implemented that is useful for students. Some teachers conclude that when integrating the curriculum, students work on meaningful tasks where they show a lot of expertise. The teacher can use one job to assess various fields of study. In one activity, for example, the teacher can assess student learning progress in the fields of mathematics, art, and writing.

Thus, integrating the curriculum in a real-life context makes it easier to see how knowledge will be useful for students. With an integrated curriculum, many teachers teach not only to convey facts and skills, but will prepare students to live as productive citizens. Many teachers report positive results such as higher-level thinking skills, applying knowledge to solve real problems, collaborating, and being creative. In addition 
students will care about issues, participate in life, and overcome problems in a cooperative atmosphere. The focus is students who learn to be critical thinkers so that they can better represent their community in real life.

\section{ACKNOWLEDGEMENTS}

The researcher would like to thank Sussan M. Drake and Rebecca C. Bruns for the extraordinary work "Meeting Standards Through Integrated Curiculum".

\section{REFERENCES}

Drake, S.M. \& Bruns, R.C. (2004). Meeting Standards Through Integrated Curiculum. Alexandria: Association for Supervision and Curiculum Development (ASCD).

\section{Authors:}

*Taseman, M.Pd.I. (Corresponding Author)

Institute University of Islamic Al Khoziny Sidoarjo, Indonesia

Jl. KH. Khamdani Rt 1/Rw 1 Siwalan Panji Buduran, Sidoarjo 61252, Indonesia

Email: taseman@alkhoziny.ac.id

\section{Wilujeng Asih Purwani}

University of Billfath, Lamongan, Indonesia

Jl.Kh. Ponpes Al Fattah Siman Sekaran Lamongan, 62261, Indonesia

Email: wilujengasihp@gmail.com

\section{Safarudin}

IAIM Sinjai, Indonesia

Jl. Sultan Hasanuddin No 20 Sinjai, Indonesia

Email: sarthi339@gmail.com

\section{Nasrul Fuad Erfansyah}

Islamic State University of Sunan Ampel, Surabaya, Indonesia

Jl. Ahmad Yani 117, Surabaya, East Java, 60237, Indonesia

Email: erfansyah83@gmail.com

\section{Ratna Pangastuti}

Islamic State University of Sunan Ampel, Surabaya, Indonesia

Jl. Ahmad Yani 117, Surabaya, East Java, 60237, Indonesia

Email: ratnapangastuti@hotmail.com

\section{Abd. Malik Dachlan}

Tarbiyah High School of Al Ibrohim, Madura, Indonesia

Jl. Raya Galis No.03, Bangkalan 69173, Jawa Timur Indonesia

Email: malik.dachlan@gmail.com

\section{Nukh Khozain}

Tarbiyah High School of Al Fattah, Lamongan, Indonesia

Jl.KH. Ponpes Al Fattah Siman Sekaran, Lamongan, 62261, Indonesia

Email: nukhozain04@gmail.com 